\title{
Hromádka and Aspects of Power in Our Civilisation*
}

\author{
JAKUB S. TROJAN
}

As early as the beginning of the 1970 s, during the first moves towards normalisation, when a whole series of institutional platforms in the church and in public life were being liquidated, and when it was becoming taboo to talk about political issues, Jan Capek reminded us that it was our duty not to abandon our responsibility for public life. He was afraid that if we did, it would harm the very basis of our faith, and the positions which we had held up till then would be discredited. He realised that if we did ignore this responsibility, then it would also mean that our intellectual work would gradually waste away and the universal perspective of our responsibility would be lost, because theological debate, if confined purely to church circles, would gradually take on the character of a private interest.

This warning was a serious one, which remained relevant in the years that followed. Were we going to be able to find a sense of direction in a period when, after the invasion by Warsaw Pact troops, prospects for the eastern type of civilisation reforming itself seemed quite minimal? Was there still any point in trying to improve conditions in a country which, after the promising reform movement of the $1960 \mathrm{~s}$, had been transformed into a murky backyard of Soviet expansion, maintained exclusively by the exercise of power? Did not August 1968 and what followed on from it in Czechoslovakia serve to confirm that not only the attempts at reform on the part of enlightened communists, but also our own activism, motivated by our Christian faith, were now off the agenda for a long time, if not for good? Did it not mean that a thoroughgoing revision of our social activity was called for, and that it might even be necessary to abandon it completely, because practically every sphere in which it could take place had been eliminated from above? Some of us asked ourselves whether this was not a sign that we should test out the validity of the aims and perspectives which we had shared within the 'New Orientation'. ${ }^{1}$ The break-up of the 'New Orientation' should not be attributed just to the fact that when we had lost our of ficial licences to act as preachers we came up against a shortage of official platforms where we could meet and reflect together, that we were becoming increasingly isolated, and that we had to take on new jobs. It can also be explained by the fact that we tried to find new sources of spirituality and motivation for ourselves and for our work, so that in addition to the externally imposed dispersal which occurred when we were expelled from the church, internal differences of opinion also emerged. Reflecting on this spiritual shift of emphasis which all of us went through in the years after 1968 is a task that we all ought to set ourselves. For it can be seen that on some

*This article was originally delivered as a lecture to Jan Čapek's congregation of the Evangelical Church of Czech Brethren in Sázava in April 1988 in the course of a symposium on Hromádka. 
basic questions we are no longer in agreement, and that sometimes we have even adopted completely opposing positions.

At the beginning of the 1970s, we looked back for guidance to the theology of Josef Hromádka. We were obliged to test the validity of his legacy under completely changed circumstances. Hromádka made such a deep impression on us; he was a figure whose importance transcended the Protestant churches, and had an impact on many debates on intellectual, social and church issues over a number of decades, both in Czechoslovakia and in worldwide ecumenical circles. However, the reason why we looked back to Hromádka was not just the obligation we felt towards someone whose words could not be ignored. Many of us were stimulated by him personally in a number of ways. He influenced us on an intellectual and on a human level. Listening to his expositions, lectures and sermons was for me, and I believe for a significant proportion of friends of my generation, a powerful experience. This is all the more reason for us to be concerned that the voice of Hromádka has somehow fallen silent for the young generation of today. Is it simply because those who interpret Hromádka for the young generation of theologians at the theological faculty today have passed over in silence the essential and often contradictory aspects of his work? It is possible that this is the case. But this in itself is not enough to explain why Hromádka has become a withered, if not completely dried up, tree in the garden of the church.

\section{I}

In this article I will try to reflect on a problem which could be roughly described as the question of power structures, although in quite a broad sense. I will not restrict myself purely to political issues, which can be related exclusively to the ruling elite. What I have in mind when I refer to power includes all the profound social, spiritual, cultural and intellectual preconditions which are necessary for that power to be exercised, and their relationship with the institutions which that power makes use of.

Hromádka reflected on these issues constantly throughout his theological career. Under the first Czechoslovak Republic he confronted official government policy, personified by T.G. Masaryk. He was at the same time its supporter and its critic. He appreciated and had a positive view of the foundations of the life of state and society as conceived of by Masaryk - later he often recalled Masaryk's idea that states are sustained by the ideas out of which they originate. However, particularly around 1930, he became aware that democratic society in Czechoslovakia, as elsewhere in Europe, suffered from significant disorders, especially in the sphere of social justice. It was clear for Hromádka that even the best state and social systems are burdened by failings, and he drew a sharp line between them and the Kingdom of God. Hromádka is concerned with the sovereignty of the gospel. This is his yardstick for all human programmes, which in spite of their relative historical justification he sees in the final analysis in the light of the cross of Christ. ${ }^{2} \mathrm{He}$ is concerned with the liberation of the church from intervention by state, nation, tribe or family. He knows that the church must never become the servant of worldly interests. 'It would be a mistake if political or other activities were to take the place of access to the soul and conscience of the whole of the people. The church has a task: to be the guardian of the people. ${ }^{3}$ It has to raise its voice 'whenever wrongdoing and injustice take place, whenever consciences are obscured and the people are no longer able to distinguish between truth and lies, right and wrong, virtue and vice, God's will and sin. The churches must not be silent about state violence, the exploitation of the poor and the vices of the rich and powerful."4 
In these interwar sermons and articles, the influence on Hromádka of the dialectical theology of Barth and his friends can be seen. From them, as he himself admits, he learned to distance himself from all attempts (although some of these attempts may have been historically successful) to create a synthesis of human, cultural, moral or political elements with the consequences of the Christian message about God and his kingdom. He concentrates his attention on the abandoned, marginalised members of the human community, who are forced by the powerful into a position where they have no rights, on those who are economically exploited, generally held in contempt, and exposed to all possible forms of pressure. It is to these people that hope must be given; and at the same time, the conscience of those in power must be shaken.

To the same period belongs his struggle against the corruption which threatened the whole of Europe in the form of German Nazism. He is aware of the danger arising from this for German Protestantism. It is exciting to read Hromádka's enlightening and theologically profound analyses of the way the situation developed after 1933, both on the political scene and in the area of the church. He realises that the German church is exposed to a similar temptation as was cultural Protestantism at the end of the nineteenth century, when it attempted to achieve a synthesis of biblical elements with cultural and spiritual traits typical of the day. He criticises German Christians for allowing themselves to be dragged along in the wake of the prevalent national feeling, for giving their blessing to racist ideology and slogans, and for rushing to climb on the bandwagon by creating something as repugnant as a German type of Christianity, with an emphasis on religious purity (without Jews!), discipline and the Führer principle. The following words have a prophetic ring:

The church which does not allow itself to be deafened by public opinion, which is not under the control of the passions of national and state life, which perhaps as a consequence loses popularity and is persecuted, is never in such great danger as the church which lends its blessing to everything that happens, accompanied by bells, hymns, robes, and the sound of the organ. If it is not to falter in its duty of remaining on the watch, the church requires tremendous spiritual strength and courage. A church which loses this courage ceases to be a church of the Lord and becomes a servant of Antichrist. 5

Hromádka formulates his attitude towards state and social power in a positive way.

The Lord God wants to rule over the entire world. . . Not a single area of life is allowed to escape from his authority; all are equally under God's authority, the cobbler making shoes, the workman on the building site, the minister running the state, the mother suckling her child, the writer writing his book and the professor developing his theories. All of us are perfectly equal in that the Lord God keeps watch over us and speaks to us. ${ }^{6}$

According to Hromádka, the role of the church in a time of upheaval like the $1930 \mathrm{~s}$ consists in becoming a community of people, a spiritual home, out of which will emerge responsible, penitent people, in solidarity with, and in concrete situations in the service of, all those who suffer, the handicapped and disorientated. The church has to break through the ideological scheme to be capable of accepting people just as they are, and to be a place of renewal of human relations. The church has to react to everything in a manner different from that which is usual in civic life; it has to be a place open to everybody. And at the same time it has to challenge and refine the human conscience through the message of the Gospel, to offer help to all those for 
whom the world no longer holds any hope. It would be a mistake, however, to understand this description of the church's role to mean that in times of upheaval the church should simply become a place of refuge, and should abandon the universal perspective of the renewal of the whole world. Hromádka once again emphasises the urgent duty of remaining on the watch. The church has to call the whole people to be responsible and obedient to God's law: 'If the church did nothing else than sound the alarm when wrongdoing and violence occur, then it would be doing enough.' And again he reminds us:

being the watchman of the Lord calls for inner strength, freedom and courage. It requires vigilance, the ability to scan the horizons and to be a sensitive observer, experience, and spiritual courage and flexibility. A drowsy and subservient church is salt which has lost its savour - it is an opiate against which people struggling for greater humanity and justice rightly rebel. The church as a vigilant watchman has on its side the Word of God and of the Crucified Christ. ${ }^{7}$

The power and dynamism of evil must be opposed by the power and dynamism of the Holy Spirit. Everything depends on the courage of our faith, which sees above the world the sovereign majesty of the Lord and all his might, the cross of Christ, the full gravity of his judgment and the selfsacrificing nature of his mercy. ${ }^{8}$

\section{II}

With a belief in the sovereignty of the power of God's gospel over worldly systems, with an emphasis on the responsibility of each person for all areas of life and on repentance by Christians, who should recognise their share of guilt for the vices of society, with the desire that the church should be a place of renewal of personal and public life at a time when, at the end of the 1930s, all historical supports were collapsing: it was thus equipped that Hromádka set sail for the United States. It was the period after the catastrophe of Munich; the first Czechoslovak Republic lay in ruins, abandoned by the allies who had assisted at its birth. Hromádka realised that Europe, as represented by France and England, had ceased to be a guarantor for democratic principles, freedom and spiritual energy. Its social systems had turned rotten, because they were not supported from below by the spirited and self-sacrificial enthusiasm of their citizens. With anxiety Hromadka followed the rise of Nazism and fascism, and the possible threat that both might come to form an alliance with bolshevik atheism, which would catch not only France and England, but also the United States of America, in a state of exhaustion, scepticism and desire for false appeasement. And once again he emphasises the fundamental principle of the overlordship of Christ, the sovereign power of the gospel over the whole world.

We have only one king, whom we must obey above all else. And when earthly rulers and kings want to overshadow the authority of Christ with their own power, then the church is called to proclaim its loyalty to the heavenly Lord with all determination and to call on the worldly lords to profess obedience to the Crucified Lamb. ${ }^{9}$

Once again he proclaims the freedom of the church in relation to the world. This freedom does not originate in a lack of interest in public affairs, but in the conviction that it is only by maintaining a distance from the institutions of power and their 
representatives that it is possible to practise unalloyed responsibility. He reminded the American public of the heritage of our 'Unity of Brethren', and wrote, 'At this time, especially, we can learn from the Brethren to unite the admirable freedom of a believer's heart with responsiblity for the world, with the effort to ensure that all worldly systems, social and political, conform to God's system.'10

It is in this spirit of critical loyalty that Hromádka passes judgment on American political and church public opinion, struggles against isolationism, and calls on Americans to take on some responsibility for Europe, in the organisation of which they played a significant role after the First World War. In the articles, lectures and sermons which are collected in the book $S$ druhého brehu (written together with O. Odložilik), Hromádka's close bond with Europe and with his own nation is apparent. He reflects on the causes of the tremendous catastrophe which Europe (and with it the whole world) is going through, and he does not find them only on the level of high-profile politics or of material and social processes. He probes deeper, on the spiritual and moral level, and everywhere he sees hazardous cracks, precipices and chasms. He recalls Masaryk's analysis of the contradictory soul of modern people with their scepticism, weariness and exhaustion, which leaves its mark on every kind of historical event: because spiritual powers of resistance are not sustained by a sense of sacrifice and constant self-renewal, their institutional form also disintegrates by degrees. Weary humanity, stumbling forward without any profound convictions or loyalty to the truth or to ideals of justice, is in no position to offer any resistance to the pernicious onset of nihilist forces. The fate of individuals is suicide, the destiny of societies is disintegration. Here, with some distance between him and events in Europe, and yet closely linked with them, in theological reflection and spiritual solidarity with those who lay bleeding on the battlefields and dying in the concentration camps and places of execution - here, Hromádka once again emphasises the liberating power of the gospel, which cannot be confined to any of the levels we mentioned above, which goes beyond all of them and at the same time inspires them all. The influence of the gospel is difficult to perceive from a cursory external inspection, but it is nevertheless real. The voice of the prophets and apostles cannot be ignored even amidst the deafening din of the world. That voice sharpens our sense of hearing so that we can detect underground rumbling - to coin a phrase often used by Hromádka - so that we can notice hidden, hardly perceptible forces, which begin to influence the tissue of history. It makes it easier to discern the invisible tremors which soon break through to the surface, leading to the volcanic eruptions and avalanches which affect a wide area around the epicentre. And so new formations and configurations of power start to appear in the massif of history, which were previously either not noted at all, or else were active only on the periphery. From 1941 onwards, at first occasionally, and then increasingly frequently, Hromádka noted this process at work in the eastern part of Europe, especially in the Soviet Union. The credit of the two prewar powers, France and Great Britain, had been seriously weakened: both countries were so lacking in foresight as to give the destructive forces of Nazism and fascism room to manoeuvre. They could no longer be counted on, therefore, to act as the main forces for renewal after the successful conclusion of the war in Europe. Paris and London were replaced by Washington and Moscow. This was already clear to Hromádka in the middle of the war. In his analyses of the situation he pointed to the essence of the crisis: the old world is collapsing (which is the title of one of his essays of this period). He increasingly came to see the way out of this crisis as lying in a postwar alliance between the United States and the Soviet Union. 
He hoped that a great synthesis would come about. One part of it would consist of the traditions of the West, embodied in the clear-sightedness and profundity of spirit of France, the practical nature and love of freedom which England brought to the world and the emphasis on the rights of the individual, the individual's independence from state power, the sense of competitiveness and technical inventiveness which was the American genius. The other part of the synthesis would be formed by the immense desire for social justice, fraternal solidarity among people and peace which was expressed in the eastern, and especially the Russian, tradition.

As the end of the war approached and the subject of postwar renewal came to take up more of Hromádka's thoughts, he began to call ever more forcefully for a new synthesis, this time a more profound and lasting one. It is particularly interesting to follow this line of his, because we are dealing here with a dialectical theologian. Does not this direction in his thinking show that the problems surrounding liberal theology have not been definitively resolved, and that they still force themselves onto today's agenda? Or to put it another way: will not theologians need to resort to the main emphases of liberal theology whenever they want to deal in a responsible way with public issues in all their aspects?

The synthesis we have described would have been possible only on the condition that the West underwent a change and overcame its fear of everything coming out of the East. For the isolation of the Soviet Union in the 1930s and the attempt to weaken it militarily with the help of Hitler's Germany only deepened the crisis and brought unspeakable suffering to the European nations. At the same time Hromádka was convinced that the Soviet Union was undergoing a change. He wrote,

If you listen carefully to the news from the Soviet Union, then you can sense that there, too, tremendous longing for social change has joined with the immense forces which have stirred the Russian soul for centuries. The renewal of the Patriarchate is not simply an external gesture or a clever tactic. The dissolution of Comintern has deeper consequences; it is not simply an adroit manoeuvre. ${ }^{11}$

Hromádka believed that only 'an atmosphere of good will and sincere cooperation will help... the positive peaceful and humane forces in Soviet Russia to achieve a lasting victory'.

Everything indicates that the spiritual forces which for centuries formed the hidden backbone of Russian education, literature, art and thought, are now awakening and renewing themselves in the Soviet lands. The Soviet Union stands today on the theshold of enormous spiritual, intellectual and cultural possibilities. An atmosphere of collective security and world cooperation would fall like a spring shower on Soviet soil and make it fertile... in the same way as links with Russian traditions would help to achieve social justice in the renewed democracies of the West.

'A lack of trust and international tension', he feared, 'will, however, stifle and suppress the pleasing developments we see today which are linked with a great social experiment in a greater unity.' 12

So Hromádka entered the postwar era in the hope that both East and West would undergo a purifying change and would join their traditions together in a greater unity. A return to the world as it appeared before 1939 was not possible. He emphasised this message particularly strongly to the western countries; but even face to face with the East he expressed the hope that the horrifying and unfeeling bolshevik dictatorship, 
which had shocked world public opinion, particularly by the monstrous trials of the 1930 s, also belonged to the past. Naturally risks still remained, but it would depend on the boldness and resolution of those in positions of responsibility, the wisdom of statesmen and the progressive forces of good will as to whether a brake would be put on wheels which were turning in the direction of a glorious future.

\section{III}

Hromádka returned to his home country for good in 1947 with the conviction that postwar reconstruction would require in every country statesmen of great stature, who would recognise the importance of the great moral and spiritual values, who would have a broad outlook and who would be willing to work together with others at the task of national renewal. On the Czechoslovak scene such a politician, according to Hromádka, was Edvard Beneš, who was deeply rooted in the Czechoslovak tradition which (as Hromádka wrote when he was still in exile) 'was embodied so mightily in the spiritual, social and political humanity of Masaryk'. ${ }^{13}$ When speaking of the Czechoslovak 'tradition', Hromádka had a balanced synthesis in mind. In contrast to the communists, who returned from Moscow with an unequivocal emphasis on a pro-Soviet orientation in all spheres, Hromádka wrote: 'I consciously reject a one-sided eastern orientation. I do not want to kill the creative tradition of our history. I do not want to renounce the many mighty spiritual struggles waged by the West.' ${ }^{14} \mathrm{He}$ contemplated working on a true internal synthesis of western and eastern civilisations 'on the border between East and West'.

\section{IV}

February 1948 saw the communists take power in Czechoslovakia. Hromádka reacted to these events in an article in Krestanská revue, which in my judgment achieves a remarkable harmony, and in which one could say he withdraws with interest the investment of the clear-sightedness with which he had forecast developments in the eastern part of Europe many years in advance. ${ }^{15}$ Soon afterwards he wrote an extensive article for the preparatory booklet The Church and the International Order for the first General Assembly of the World Council of Churches in Amsterdam in summer 1948. It was included in the a collection of Hromádka's works published to mark his eightieth birthday in 1969, and its contents are worth examining.

Right at the beginning Hromádka asserts that the basic problem of the time is 'something much bigger than the problem of freedom and democracy'. (He had already considered how dispensable democracy was in his article 'Evropská tragedie po pádu Francie', in which he had said that without their spiritual, intellectual, moral and constitutional heritage Europe would cease to be Europe and America would cease to be America. To democracy, he now added freedom.) According to Hromádka, this basic problem is something which lies

outside the categories of capitalism and socialism, liberalism and communism, yes, which goes beyond what we call the mutual exclusiveness of free society and a totalitarian system, the democratic West and the communist, regulated and controlled East. The whole of civilised humanity is sick.... We are living in a crisis which is more than a crisis of democracy and freedom, liberalism or humanism. ${ }^{16}$

What does this crisis consist of? 
It is a question of the ultimate principles and axioms of truth, justice, personality, love and organic moral society. People of today in both East and West no longer understand the concept of the highest authority and the highest judge, to whom all people, nations and races are subject in order that they might come to mutual understanding and find common ground on which it would be possible to start building a new and better order of things. ${ }^{17}$

Hromádka wrote this at a time when, as the result of the well-known events which took place in Poland, Hungary, and finally Czechoslovakia at the end of the 1940s, the ominous cloud of the Cold War was beginning to gather on the international horizon above the attempts at cooperation of the victorious forces, and when Hromádka's vision of a new worldwide synthesis was fundamentally threatened. At that time the human race still had no idea of the problems that were in store for it as a result of the accumulation of huge arsenals of nuclear and chemical weapons, nor of the abyss that would open up in front of it through the threat to the planet's ecosystem.

In the face of this gathering crisis, Hromádka relies on the perspective of the biblical message. Here again speaks a dialectical theologian who is aware that the gospel cannot be transferred to the cultural, moral, political and other values which the human spirit strives to attain. Only three years had elapsed since the end of the war, and already it seemed to Hromádka that the prospects for his grand synthesis were in ruins. He emphasises the movement of incarnation, the descent of the holy, just and merciful Lord from 'the highest heavens to the deepest valley of human transgression and sin, in order to break the fetters of guilt and death there where it seems that nothing can prevent the power of impious and destructive evil from triumphing over Christ and his Kingdom.' That is the vertical seam which is able to hold together things that would otherwise fall apart in mutual alienation and enmity. This perspective of the Lord's presence makes it possible to do two things: to acknowledge our own share of the blame for the catastrophe which we have let ourselves be dragged into; and at the same time not to give way to despair, to see ourselves as being people who have been liberated from our prejudices and our deadening scheme of things.

Then comes a section entitled 'The problem of the West'. I quote here the opening passage.

The people in the Eastern European bloc... have a profound respect for the vigorous tradition of the European (and American) West. The break-up of western civilisation would mean a tragedy for all the great values, which are also loved and honoured by the people in the East. Making man subject to God, the Creator and Saviour, the God of grace and justice, the Lord of history, who leads us towards the final victory of truth and merciful justice; making the earth and passions subject to the clarity of reason and the majesty of a watchful conscience; justice as the norm which is supreme over power; love as the force of fusion for social life; the freedom of the responsible personality in regard to the claims of human authorities over the souls they rule over.... The people of the East, regardless of whether they stand on the right or on the left politically, would tremble with fear, if these great ideas should cease to be the leaven of our personal and public life. ${ }^{18}$

Hromádka then raises six points in which he expresses his doubts at to whether the West is capable of fulfilling its responsibilities towards civilisation, because, due to its 
weakness, these great principles and values are losing their attraction. The western democracies are lacking in integrating and creative potential. They are responsible for the appalling crisis which Europe has experienced during both world wars. They will not have the strength, believes Hromádka, to build up a new order on the basis of real social justice. They are motivated rather by the material, economic interest of the big industrial and financial concerns, which undermines the vitality and profundity of the principles mentioned earlier. The western countries fail to understand the changes which are taking place in Eastern Europe - although to be frank it is impossible to justify the methods and actions of those who have come to power there. Hromádka does not hide the fact that if

the West were to squander its treasures through its lack of faith, its spiritual indifference and self-contentment, then a bleak atmosphere would deprive the whole European continent (including the East) of its internal resilience and creative force for a long time. The struggle for human dignity, for the sacredness of the individual and for responsible freedom, without which our life would be gloomy and sad, would then have to be carried out under very difficult conditions and circumstances. ${ }^{19}$

It is, incidentally, in this same tone that he addresses words of warning to those who came to power in Czechoslovakia in February 1948, in the article 'Po únorové krizi' referred to above.

Immediately after this there follows Hromádka's fifth point, which is a criticism of formal democracy, formal freedom of thought and speech. This, he asserts, is not a goal in itself. What the mass of ordinary people are interested in are the goals and tasks which the freedom of free institutions can serve. In generalised terms, Hromádka talks of nations whose situation reminds us of a flood destroying towns and villages, of a fire taking control of a town, of a volcanic eruption covering a wide area in ash and ruin. 'How can we expect that democracy can function normally under such circumstances?' he asks. 'It is not political freedom which is really the most essential factor, but a well-conceived and reliable plan for a new society, founded on social justice, human dignity and lasting peace. ${ }^{20}$ The western democracies should understand this and cast aside prejudice and fear with regard to the eastern countries; they should avoid oversimplification and aim for greater understanding. 'A new insight into the true foundations of western culture... can open our eyes to the longings of the nations and masses of the people, who awkwardly, inexpertly, forcefully and headlong seek to secure their place in the sun.... This danger can be overcome', writes Hromádka at the conclusion of this section, 'if we have a sympathetic understanding of the longing of the masses of the people in the East for greater human dignity, social equality, cultural progress and an adequate share in political responsibility for constructing a world order.'21

In the section entitled 'Problems of the East (the Soviet question)' he turns his attention in the opposite direction: 'We must know, understand and explain the situation in the eastern sector as fully as possible. ${ }^{22} \mathrm{He}$ admits that there exists a tendency to interpret the political and ideological structure of the Soviet system as a new manifestation of modern totalitarianism. This is due not only to the fact that western people are excluded from the Soviet world by historical and geographical barriers and ways of thinking, and exposed to the influence of propaganda, but also to a number of things which are going on behind the Iron Curtain. In this connection, he criticises attempts to understand the Soviet system as being analogous to Hitler's Germany. 'The configuration of communism and its essence differ from the con- 
figuration of Nazism. ${ }^{23}$ It does not have a metaphysical level; its atheism is more a practical reaction against the forces of pre-socialist society - tsarism, relying on the obsequious service of a willing Orthodoxy. Communism owes its vitality to a fascinating idea of a society, in which all people will be liberated from greed, from Mammon and from the tyranny of materialism, and in which a community of human beings will be formed who really live in mutual sympathy, love and good will. 24 The classic theory of communism is, according to Hromádka, secularised Christian theology.

Hromádka admits that the principle of dictatorship played a major role in the days of the revolution and civil war and in the transitional period of socialist reconstruction. However, he considers it a mistake that contemporary communist leaders in various countries also lay too much stress on dictatorship, to the detriment of the positive idea which consists in the struggle "for a social system in which class differences will disappear, the demonic and tyrannical power of money and private ownership will be broken, and all people will come together on the common ground of human dignity, freedom and love.'25

Hromádka goes on to appeal to the reader to try to understand what is happening in the Soviet system, with its vigilance and harshness, by considering the background of Russian history, particularly of the revolutionary epoch, the civil war and various interventions by foreign powers.

If we make an objective and accurate assessment of the backwardness of the masses, the relatively swift reorganisation of this whole (enormous) country, the defeat of both domestic and foreign enemies and the astonishing transformation of the old social system into a new, socialistcollectivist order, then we will certainly be greatly impressed by the extraordinary energy, adroitness and organisational inventiveness of the ruling party. ${ }^{26}$

We must not measure Soviet reality by abstract political yardsticks; it cannot be compared with democratic institutions and methods which grew up in a very different political climate. The dictatorial regime of the Soviet system should be understood as a historical necessity. Hromádka refers to communist philosophers and statesmen who emphasise the transitional character of the socialist dictatorship of the proletariat. He is, however, aware of the demonic temptations of power and the desire for power. It is a constant danger for those who rule by extending their uncontrolled authority in unconstitutional ways. However, he believes that the further the process of building up the socialist system progresses, the less need it will have of dictatorial power, until eventually all forms of dictatorship will disappear in a fully developed, completely collective and classless economy. 'Regardless of its ideas or practice of dictatorship' he writes, 'communism is essentially neither absolutist nor totalitarian. Inherent in the communist world view is an orientation towards the total liberation of the human being.' 27

Here, according to Hromádka, we come once again to the gospel. For this positive outcome to become a historical reality, for it to be possible to unite post-revolutionary society in one living whole of true confidence and free responsibility, and thus to preserve the fruits of the social revolution, it is necessary to appeal to those elements in humanity which go beyond the material, historical process. 'Even a classless society cannot acquit itself creditably without God's judgment, eternal justice and forgiveness. ${ }^{28}$ Hromádka is obviously hoping that Russian Orthodoxy, in spite of its 
grievous wounds, victims and losses, will remain alive and will undergo renewal. He believes that

the church, which understands the signs of the times, and knows where and with which weapons it has to fight, is still capable of carrying out its service. Social and political systems come and go. But the message of the living God, the incarnate Word, the crucified and risen Lord, and the creative Spirit remains for ever. ${ }^{29}$

At the end of his study he puts forward several theses. He believes that the Soviet system cannot be transplanted to any country which has a different historical, moral and cultural tradition. It has its roots in soil which has been ploughed and cultivated by Russian people from the Russian church and the Russian intelligentsia. This system, continues Hromádka, would however be affected

if the great traditions of western culture were to be seriously wounded from without, or faded away from within because of their moral and spiritual decay. What would become of the great Soviet ideals and goals, if the western struggle for the dignity of responsible human beings under the authority of the eternal norms of justice, truth, purity and love were to end in despair, cynical pessimism, spiritual indifference and disillusionment? ? $^{30}$

The West can only hand down, give new life to and pass on the heritage of its culture to people from other parts of the world on one condition: if it holds fast to what the creative genius of European and American history has given rise to in the way of political, intellectual and social progress. That means overcoming the system 'of free enterprise, private property and achieving a life of ease'. The West must of course also renounce the atomic bomb.

Right at the end of his section on the 'Soviet question', Hromádka identifies three areas of serious and justified concern:

1 Enormous power is concentrated in the hands of those who rule in this part of the world. The danger that Soviet attempts to achieve social revolution conceal a renewed drive for expansion of the old Russian empire is a real one. The union of revolutionary socialism and Russian nationalism may bring with it a terrible temptation to rule the world and give rise to a new historical catastrophe.

2 If it does not meet with resistance and criticism, the world view of dialectical materialism, which rejects all norms outside history and sees human beings simply as products of their social and economic environment, might open the way for purely animal desires, rancour, hatred, avarice and self-assertion. It is up to the Church of Christ to construct effective restraints, and through its witness to form an unshakeable core of moral norms, legal concepts and social yardsticks, without which a new barbarity might well expand throughout the whole world.

3 Hromádka considers it to be unclear whether the revolutionary tradition and Marxist materialism will be capable of respecting the sanctity of the human person and of freedom. He is taken aback by the way in which representatives of eastern regimes deal with political opponents and minorities. Instead of trying to persuade them, they prefer to operate using propaganda and attacking them. The eastern peoples would receive a lot of support if they did not use so 
much loud propaganda and if they spoke with the genuine pathos of truth, sincerity and honesty. He appeals to the leaders of Soviet society and the communist parties to rely less on violent inflammatory methods, threats, propaganda, deportations, trials and police control, and instead to arouse in people the noblest feelings of sympathy for the weak, the poor, the powerless and the wretched. They should have their eyes open for what in the final analysis is the heart of socialist humanism.

\section{$\mathbf{V}$}

At this point I would like to summarise the argument so far and add some critical remarks of my own. Hromádka is consistent in his conviction that the gospel of Christ cannot be reduced to the level of any conceptual form, point of view or institutional guise, nor made to be part of historical socio-political experiments. The sovereignty of the gospel applies in all circumstances, changes and times of upheaval. It is the supreme norm, by which we measure all human works and mutual relations between people. It extends beyond all intellectual, social, economic, political, spiritual and religious levels. Indeed, it is the source against which it is possible to measure and critically evaluate all these levels. Basing itself on the gospel, the church has to carry out its duty of remaining on the watch face to face with the systems of power in a spirit of free responsibility and at a critical distance.

Hromádka does not in my opinion fall into the trap of forgetting this supremacy of the gospel and of moving to a position which might in simple terms be described as that of a theologian or philosopher of history. His principle remains that history must be taken seriously, but should not be allowed to take control. In his view, gaining control over history means, among other things, being able to distinguish between its superficial and deeper levels. And this is not possible except from the perspective of faith in the sovereign rule of God over history, or, to put it in philosophical terms, from a firm standpoint which goes beyond history.

Nevertheless, it seems to me that this theological standpoint, during the time of the first Czechoslovak Republic and Hromádka's stay in America, was thought out in the context of a society which was at least nominally Christian (the USA) or which had by no means alienated itself from Christianity (the period 1918-1938 in Czechoslovakia), and that consequently it was possible to link up with roots and movements on the domestic scene in the context of spiritual and moral principles which were more or less acceptable to public opinion. However, after the end of the 1940s the situation altered radically. Society began moving away from the Christian tradition as it experienced secular development, rapid and revolutionary socioeconomic changes and violent administrative methods. This society could no longer be addressed directly, partly because the church was seen as a constituent element of the 'old mentality'; society was creating a new philosophical vocabulary, which was producing a mentality based on different ideals and viewpoints from those prevalent in the society in which Hromádka grew up and worked for the greater part of his life. The question now arose with some urgency: how was it going to be possible to carry out the critical programme which Hromádka envisaged?

Proclaiming the overriding responsibility of the individual in a society in which that individual is lost, a society which talks in terms of five-year plans and voluntary workgroups, which has a hierarchical organisation, which has established a system directed from above, and which is aggressively promoting a collectivist mentality; speaking of 
the majesty of love, faith and hope as basic categories of human existence and persisting in appeals to truthfulness and the longing for forgiveness when at the same time pressure from those in power on the one side and attempts to conform with them on the other are a daily reality; proclaiming the Crucified Christ, who descends to the uttermost depths of the human individual in order to carry out his work of renewal, while the regime is proclaiming the maintenance of the private sphere to be a sin, and at the same time is itself interfering in it in innumerable ways: all this seems like ineffective rhetoric, a vain attempt to bridge a gap which opened up practically overnight between two stages in history. It is true that Europe had experienced something similar in the 1930 s, when Hitler was elbowing his way to power. A wave of dynamic nationalism was beginning to see itself as a movement based on race, the fatherland and the leadership principle. At that time certain German Christians attempted to bridge the gap between themselves and these new developments by ideologising the Christian faith. They restructured their Lutheran Reformation heritage into a form which would be acceptable to the Nazi movement. However, this was not possible in Czechoslovakia after February 1948. Those in power, unlike the Nazi leaders, were not interested. Marxism, with its determined atheism, did not provide any stimulus for this kind of move. Those at the top of the power structures were basically concerned to neutralise the influence of the church in the political field.

It is clear, then, that in this era Hromádka was trying to do two incompatible things. On the one hand he was attempting to stress that the Christian faith is unique and that there can be no substitute for it when building up new social systems. At the same time, in ecumenical circles both at home and abroad, he became an advocate of the fundamental changes which had taken place in the eastern part of Europe. Somehow he overlooked the tension which exists between the Christian faith, particularly in its anthropological aspects, and the model of reconstruction which was being implemented in Czechoslovakia in the 1950s. In western societies whose links with the Christian tradition remained a historical fact, there was an emphasis on freedom and democratic social forms, in which the independence of citizens from the power of the state, respect for the convictions of others and so on played a dominant role. No such emphasis is apparent in Hromádka's speeches of this period, even though in the document for the WCC which we have discussed he still considers these things to be essential spiritual and moral values for every healthy society. The image of the burning town, the flooded land - why this anonymity? - with which he tries to account for a failure to implement formal democracy, and positive emphasis on discipline, service, responsible self-control and self-sacrifice come into the forefront of Hromádka's thinking, and from here it is only a step to proclaimining a moratorium on criticism, as indeed happened in the 1950s. And the reason? The guilt of the Christian churches in the past is so great that we have no right to open our mouths, and it is necessary to give those who are shaping the new order time so that they can continue in their work without any interruption. In my judgment, Hromádka's mistake here was not the fact that he stopped striving for the synthesis which he had still believed in at the end of the war and for a few years afterwards this tension between dialectical and liberal theology is something which every theologian must try to come to terms with - but that by voluntarily abstaining from criticism he deprived the maxims of the gospel of their public effectiveness. Instead of a consistent attempt to become involved, with the unique moral and spiritual weapons which are entrusted to Christians, right from the beginning of the social restructuring (which obviously might lead to conflict with the representatives of the regime), he chose the path of voluntary restraint, discipline and self-control, which meant 
ignoring everything which might be an irritating factor. Instead of an attitude based on principle, he adopted an attitude conditioned by the end to be achieved: cui prodest.

One important factor which led him to this position was what in my opinion could be described as an instrumental conception of power. Hromádka was aware of the enormous power which had become concentrated in the hands of the communists in Czechoslovakia after February 1948. He warns of this in the document we have mentioned, and is even concerned that under certain circumstances it might lead to a new catastrophe. However, he did not fully appreciate the negative effect power has on those who wield it. The danger does not just consist of the fact that power may be used on one specific occasion in an act of aggression, whether at home or abroad. It can also happen that the use of power can become permanently established as the only possible approach to problems in society. And then of course it will be necessary to come to terms with the results of the misuse of power at times when there is no alternative tool available to deal with them. For under the pressure of the arbitrary use of power, society is unable to formulate the problems which may arise in it. If some of these problems still manage to come to the surface, the rulers tend to treat them as insignificant or to put off solving them, which only serves to deepen the crisis in which the whole of society finds itself. And when finally there is nothing else for it and some kind of measure has to be taken to resolve the situation, those in power tend to confront the crisis in the old way, once again by the use of power, because they have never learned any other way, or, to be more precise, because they have not created any sophisticated mechanisms by means of which they might be able to pick up signals of problems before they become too great. They do not pick up these signals because they have already silenced the critical voices which might have been able to point out shortcomings and social disorders when they first started to be apparent. It is a vicious circle, which can be broken only by a responsible approach on the part of those who assume the burden of critical assessment. But if those sections of society which are influenced by the Christian message, and should therefore have the best spiritual basis for carrying out this prophetic function, are silent, then the burden on others who have resolved not to remain silent becomes almost insupportable. Belief in power and the distorted thinking which it brings with it, and reliance on force and brutality, including terror, is today a worldwide problem. Voluntarily maintaining silence in the face of dangerous developments in society is unwise. The essential values of moral, civic and human rights cannot be put of until later. It is no good clutching at the hope that it will be possible to bring them into the house once it is built, like furniture when you move. It is the foundations, not the furnishings, which structure the house.

Hromádka's understanding of historical transformations, as they are reflected in changes in society, is that as a result of the laxity of civilisation, the worn-out institutions of one historical epoch are replaced by those of another, which is imbued with constructive enthusiasm, self-aware and internal healthy, capable of reorganising the social structure, and inspired by an immense desire for social justice and for its citizens to live together in harmony. This is roughly how Hromádka understands the shift in the forces of history between West and East. As we have already noted, he was concerned that the best values of the previous epoch should be passed on organically to the new epoch. He made a number of appeals on this theme to both sides, some almost pathetic in character. It seems to me, however, that Hromádka's scheme of things does not allow him to notice that in the new societies it is necessary right from the beginning to create space for forces which are capable not only of transferring healthy and useful values from the former society, but also of developing them under 
the new conditions, and at the same time to make allowance for the fact that in the midst of a society which has decided to form its structures according to certain ideological models - in this case Marxist-Leninist models - problems and questions will arise which will have to be solved in ways for which there is no blueprint, and which will be tackled by groups and individuals in society which are not so closely linked with the ruling elite that they are subject to the control of official criteria. This is that barely perceptible shift of ideas and forces, that seismic tremor in the spiritual foundations, which escapes the sensory instruments of the establishment, because the latter is too much taken up with itself and its own built-in interests. In this underground rumbling (to use a favourite phrase of Hromádka's) can be heard not the troublesome noise of those who are trying to return to the fleshpots of Egypt, but the insistent sound of the future. Why did Hromádka follow developments in our society after 1965 with such reluctance, so that in November 1967 he was still relying more on official embellishments than on critical movements from below?

Hromádka, then, felt more closely involved with the leading representatives of the regime than with the muted and at times indiscernible whisper coming from all sectors of society, which were gradually beginning to find the courage to speak about themselves. This is a shortcoming which evidently has deep roots in his Lutheran tradition. Throughout his life he fought against the temptation to be too subservient to those in authority, which is a frequent outcome of the misunderstood doctrine of the two kingdoms. He always had a tendency to look at the problems of society from the elevated position of those who are in power. By means of his theological programme he wanted to support statesmen and politicians with the most effective weapons of the spirit. ${ }^{31}$ At the same time, of course, he knew that the health of a society is measured by the situation within that society of the weak, those who are deprived of their rights, the marginalised, and those who are not considered to be of any value. This tension between two solidarities - with the powerful and with the weak - and between two perspectives - from above and below - accompanied Hromádka right to the end of his life. At different times one or the other tendency grew stronger. We have to say that after 1948 the dominant influence was the one which wanted to understand those in power and to explain the motives and reasons which justified them assuming leadership positions in the countries of Eastern Europe. Solidarity with the weak and the downtrodden passed from the level of a programme to that of private intervention, which Hromádka did not shirk - and there is no doubt that in this respect he achieved a great deal. His tendency to defend the established powers from internal and external attacks, however, grew stronger, particularly after December 1957 when Hromádka and others founded the Christian Peace Conference (CPC). The theological price he paid can best be measured by the vehemence with which the questionable initiatives of the western powers in the military or international fields were criticised, while wrongs and injustice in Czechoslovakia were explained away or passed over in silence. But that is another story.

\section{VI}

In 1964, sixteen years after the 'Amsterdam' article, Hromádka wrote another study, 'Na prahu dialog', which again contains much material relevant to the issue we are examining. ${ }^{32}$ In the first half of the 1960 s, the communist regime under Novotny proclaimed the end of the dictatorship of the proletariat, the concept of the people's state, and the beginning of a developed socialist society. It was a period in which conditions became relatively more liberal: the borders opened up, and in 1963 it 
became possible for the first time to travel to capitalist countries, though only at the invitation of friends and acquaintances; in magazines, albeit at first only in specialist ones, it was possible to read articles and studies of a genuinely critical nature; on the international stage something of a thaw began in the Cold War. After the Cuban crisis of 1962, it seemed that in the era of J. F. Kennedy and N. Khrushchev the two superpowers would find a new modus vivendi; the regimes in Eastern Europe had become relatively stable, and the West evidently did not anticipate their early collapse. From the technical and industrial point of view, it was the eve of the electronic revolution. At that time, the world was not yet visibly threatened by ecological problems. After a delay of 20 years, relatively normal relations were being restored on the international European scene and calm was being established on the domestic front.

In Czechoslovakia, critical waves began to disturb the surface as a result of the first economic difficulties: the winter of 1961-2 saw a perceptible reduction in the pace of development, and for the first time there was a negative growth in national income. Energy problems appeared, and the preponderance of heavy industry caused shortages on the consumer market. Together with other problems of an economic and social nature, this led to the beginnings of a discussion in Czechoslovakia concerning basic aspects of our future orientation in all areas of the life of society.

In this situation, when the CPC had been expanding successfully for several years and the cultural revolution had finished without suppressing church and religious life, the first contacts between Marxists and Christians took place. It was at this time that Hromádka wrote his study. His intention was to look at the issues and problems which would now form the basis for a dialogue between parties which had not spoken to each other for sixteen years. From the point of view of the theme of this present article, the important points raised by Hromádka's study are as follows.

Hromádka is convinced that socialist society has weathered the initial period of internal and external threats. Those who have been constructing the new order have been successful, and 'normal service' is now being resumed. They are working hard, with determination; they have adopted scientific ways of thinking; they recognise the natural, historical and economic laws by which the course of social life is governed. They have an understanding of material reality and the material context; they are concerned to alter the social order so that it conforms to human dignity. They do not want merely to achieve a precise and profound understanding of reality, however; they also want to change it, in accordance with Marx's classic thesis. In all these areas, Christians can learn from them.

The gospel does not turn away from the world. It has good news for it. We Christians too need to know and understand the world, the society in which we live. Nor must we underestimate the importance of the laws of social and historical development. We should not be trying to moralise about those who are constructing the new order; we should not be looking back, complaining or grumbling; no, we should be lending our hand to the work which has to be undertaken. We should do this from the position of the gospel, which cannot be combined with any ideology and which cannot turn into an ideology: if it were to do so, it might then find itself in competition with secular ideologies such as Marxism. The gospel leads us to undertake specific service in specific places. We do not have anything against changes in the social order, or against the ideals of the classless society, but we should not have any illusions. We know about the abyss in the human heart, and about the faults, weaknesses and other moral disorders from which not even those who are involved in constructing a new order are exempt.

Hromádka is convinced that the main problem is to be found in human beings 
themselves. Will the people who are going to live in the new house which is already being erected in front of us be internally liberated, committed to truth and justice and immune to the love of gain and aspirations to power which would alienate them from their fellow-inhabitants? Or is it the case that old people are going into this new house?

The dialogue which lies ahead should not, according to Hromádka, be concerned with achieving a synthesis. The message of the gospel is not on the same level as the ideology of the new society being constructed. It is only the gospel message, however, which is able to ensure that compassion, repentance, forgiveness, self-sacrificing love and service remain alive in this new society, and that patient care for those who have fallen continues to be exercised. The new society will require centres of sanctity and obligations to sanctity, centres of moral and spiritual integrity. Without a profound insight into, and respect for, the human soul (such as is found in Dostoyevsky and the scriptures), our very essence will be threatened, because we will have lost respect for what is unique and special in the human personality. And what is characteristic of the message of the prophets and apostles is precisely this sense of uniqueness, of the specific nature of God's word, which speaks to the human conscience in a particular place and calls for decisions to be taken in a given and unique situation. For Hromádka the Incarnation itself is an example of this emphasis on a specific time and place. ${ }^{33}$ It is a vertical movement, a process which takes place between the Lord and a specific human soul. This is a vital emphasis for Hromádka, and he wants to introduce it into the forthcoming discussions with the Marxists. For him, it is a guarantee that human social systems and the changes which take place in them will not be judged according to abstract criteria and ideological designs - a danger which, it will be remembered, Hromádka had already warned against in the Amsterdam document.

As far as the arguments advanced in ' $\mathrm{Na}$ prahu dialog' are concerned, the critical remarks I made earlier about Hromádka's 'Amsterdam' article remain valid; indeed, they have become even more pertinent.

Hromádka is thinking only about dialogue with of ficial Marxist circles. For him, they are identical with those who are 'constructing the new order'. He does not note the fact that by the early 1960 s different tendencies were beginning to emerge in our society. He talks only about Marxists and Christians - and, what is more, only official Marxists and official Christians. Critical voices in the church were not being allowed into the CPC; and there were also at that time a number of Marxists who did not share the official line, to an even greater extent than Machovec and his associates. And what about the democrats and the humanists, who were to impinge on public consciousness a few years later? Hromádka does not anticipate and examine their views - not to mention the views of those who in principle adopted a critical stance towards the revolutionary events in Czechoslovakia after 1948.

Hromádka is not able to demonstrate the internal link between the fruits of the gospel and the specific contribution of Christians and the church on the one hand and all that forms the mental infrastructure of society, including its creative, cultural and spiritual elements, on the other. In spite of all his exalted language and his at times extraordinarily powerful descriptions of God's holiness, justice and dominion over the world, it is difficult to avoid the impression that he is not penetrating to the heart of the matter. There is no organic linking of the gospel into the institutional framework at all levels of the life of society. Hromádka has not worked out the necessary conceptual apparatus for this socially effective 'incarnation'. He has not surrounded himself with people who would systematically reflect on the philosophical starting- 
points for such an attempt, and on their socio-economic and political implications. Because he devoted all his energy to the work of the CPC, he was unable to devote enough time to concentrating on working out alternative ways of introducing the gospel in the social context of the Czechoslovak situation. What he has to say reads like a sermon, like an appeal. In spite of the fact that Hromádka speaks with fervour and inner concern, in the final analysis he adopts a line of retreat, especially when he admits several times that the task of social construction is essentially complete, that the building is about to be approved, and that according to him the only question still to be settled is which people will move into it. That there might be serious structural shortcomings, that the building might, for example, be only partially habitable, that there are a number of cracks visible in the masonry, that water is dripping through the roof, that there is no water nor gas, and that all this is affecting relations between the people living in the building - all these facts seem to escape Hromádka's notice. $\mathrm{He}$ lacks a critical awareness of the fact that even the original plans of the builders of this new house have serious defects, that the very ideology and programme which the Marxists brought with them when they started the work of construction in Czechoslovakia had been adopted from the Soviet model, and that therefore both the plans and the process of the construction work should have been subjected to a critical examination right from the start, because - as he himself came to recognise in Amsterdam - the Soviet type of revolutionary socialism can easily slip into a totalitarian course. This danger, which became historical reality in Czechoslovakia and throughout the eastern bloc, is not mentioned in the study at all. And this is an extremely serious flaw, both politically and theologically.

It only remains to make one last remark. In the famous Memorandum which Hromádka wrote after the military intervention in Czechoslovakia in the autumn of 1968, there is a passage about the Byzantine aspect of the Russian tradition. Perhaps the destructive elements which became established in Soviet domestic and foreign policy were able to do so because there was no Reformation in the historical development of Russian society, and democratic and critical traditions were lacking. Against this background it is easier to understand the birth of the Stalinist model, which was imposed violently on all the countries of the eastern bloc which found themselves under the direct influence of the Soviet Union after the Second World War. We have shown that Hromádka was aware of this fatal alternative, and indeed that he did not exclude the possibility of it in theory; but that - surprisingly - he did not believe that it would actually become a reality in our country.

I will conclude by returning to the point where I started: Jan Capek's appeal still applies today. We cannot abdicate our responsibility for developments in society, our responsibility for the political, cultural and legal institutions which are to control human relations among our citizens. The path mapped out by Hromádka is in many respects instructive, inspiring, and admonitory. His assertion that we have a responsibility for public life, a responsibility which we cannot abandon, is still valid. It is still valid to say that a diastasis exists between the gospel on the one hand and any kind of model for society and any attempts to incorporate such a model into the institutional organisation of society on the other. It is a diastasis which cannot be bridged over to create a synthesis, however attractive such a solution might appear.

It is now almost 20 years since Hromádka's death, and in that time the world has undergone fundamental changes. The western countries have demonstrated a tremendous historical ability to survive, and in many respects have taken over the leading role once more. Our responsibility for that world must therefore operate within very different parameters from those applying in the 1960s. It must have a 
pronounced ecumenical character and at the same time be deeply rooted in the traditions of the Czech Reformation and National Revival. Nor can it ignore the work of Masaryk and of those who before him taught us about the administration of public life, such as Havlíček and Palacký. We must undertake a thorough study of the phenomenon of power, which is now making an appearance on the horizon of our daily experience in an even more radical way than before. We must recognise that it is necessary to construct effective barriers against the expansionism and destruction which is inherent in power. In this context we have the obligation to fight for human rights, for the freedom of the individual and for individual responsibility. In this endeavour Hromádka can still teach us valuable lessons.

\section{Notes and References}

1 'New Orientation' was the name of a group of Christian lay people and theologians founded in 1958. Influenced by Bonhoeffer, Barth, Hromádka and Jan Hus, they were committed to an attempt to relate the gospel to political and social issues.

2 See his 'Programy pod křížem', Theologie a církev (Prague, 1949).

3 'Vira a politika', Theologie a cirkev.

4 'Strážný na Sioně', Theologie a cirkev.

5 'Církev ve zmatku', Theologie a cirkev.

6 'Katazel a sbor', Theologie a církev.

7 'Posláni církve', Theologie a církev.

8 'Naše posláni', Theologie a církev.

9 Základy naší jednoty', $S$ druhého břehu.

10 ibid.

11 'Pád fašismu: sověty a budoucí mír', $S$ druhého břehu.

12 ibid.

13 'Autorita Edvarda Beneše', $S$ druhého břehu.

14 'Naše orientace', $S$ druhého břehu.

15 'Po únorové krizi', Křesťanská revue, no. 3, 1948.

16 Pravda a život (Prague, 1969), p. 60.

17 loc. cit.

18 ibid., p. 63.

19 ibid., p. 65.

20 loc. cit.

21 ibid., p. 66.

22 loc. cit.

23 ibid., p. 67.

24 loc. cit.

25 loc. cit.

26 ibid., p. 68.

27 loc. cit.

28 ibid. p. 71.

29 ibid., p. 72.

30 loc. cit.

31 See his article 'Na rozhrani věku' (January 1944), in the collection $S$ druhého brehu.

32 'Na prahu dialog', in the collection Pole je tento svet (Prague, 1964).

33 This idea is already to be found in his prewar theological work 'Krestanství v myšlení a zivotě'. 